\title{
Serum concentration of bone morphogenetic proteins (BMPs) is not linked to serum anti-mullerian hormone $(\mathrm{AMH})$ level
}

Sayaka Ogura-Nose ${ }^{1,2,3}$, Osamu Yoshino ${ }^{1,2 *}$, Ikumi Akiyama ${ }^{1}$, Yasushi Hirota ${ }^{1}$, Tetsuya Hirata ${ }^{1}$, Miyuki Harada M $^{1}$, Hisahiko Hiroi ${ }^{1}$, Kaori $\mathrm{Koga}^{1}$, Shigeru Saito ${ }^{2}$, Yutaka Osuga ${ }^{1 *}$ and Tomoyuki Fujii ${ }^{1}$

${ }^{1}$ Department of Obstetrics and Gynecology, University of Tokyo, Tokyo 113-8655, Japan

${ }^{2}$ Department of Obstetrics and Gynecology, University of Toyama, Toyama 930-0194, Japan

${ }_{3}^{3}$ Japan Institute of Sports Sciences (JISS), medical center sports clinic, Tokyo 115-0056, Japan

\begin{abstract}
Serum concentration of anti-mullerian hormone $(\mathrm{AMH})$ is used as a biomarker in practical clinics. As bone morphogenetic protein (BMP) cytokines induce AMH expression in human granulosa cells (GC) in vitro, serum concentrations of BMP cytokines and AMH were evaluated whether there would be a relationship between BMP cytokines and AMH. Serum concentrations of BMP-2, -6 -7, AMH and FSH were measured in 25 infertility patients using EIA or ELISA kits. Among 25 infertile patients, serum BMP-2, -6 , and -7 were detected only in 10, 3, 7 patients respectively, while AMH was detected in 24 out of 25 patients. There was no relation between BMP cytokines and AMH concentration in serum. The detection rate of these BMPs in serum was much lower than that of AMH. Serum concentration of BMP-2, $-6,-7$ could not estimate serum AMH level.
\end{abstract}

\section{Introduction}

In infertility treatments, the precise assessment of ovarian reserve is necessary to plan a treatment strategy for each patient. Among all available markers of ovarian reserve, much interest has been given to anti-mullerian hormone (AMH) as a reliable, accurate and reproducible predictor $[1,2]$. AMH, which belongs to the transforming growth factor (TGF) - $\beta$ superfamily, is a product of the granulosa cells (GC) in pre-antral and small antral follicles [3]. As serum concentration of $\mathrm{AMH}$ which is derived from GC, is considered an excellent biomarker in practical clinics [1,2], it is important to elucidate the mechanism by which AMH is regulated in GC. Previously, we found that bone morphogenetic protein (BMP)-2, 6, 7 and 15 increased the expression of AMH in human GC $[4,5]$. BMP cytokines which are member of TGF- $\beta$ superfamily, are known to regulate ovarian physiology; including gonadogenesis [6,7], folliculogenesis, ovulation and luteinization in various species [8]. In the human ovary, it has been reported that GC express BMP-2 and -6 , theca cells express BMP-7 and oocytes express BMP-6, -15 respectively [4,9-13]. Given that BMP cytokines regulate ovarian function, including AMH expression, serum concentrations of BMP cytokines could be a useful marker for the ovarian function. In the present study, we validated the hypothesis whether the measurement of the BMP cytokines in serum could be a predictor for ovarian reserve.

\section{Materials and methods}

\section{Reagents and materials}

The concentrations of serum BMPs were measured using ELISA kits for BMP-6 and -7 from RayBiotech (Norcross, GA), and for BMP2 from R\&D Systems. Serum AMH concentrations were measured using the EIA kit from Beckman Coulter (Tokyo, Japan).

Written informed consent was obtained from all of the study participants. Ethical approval was given by Tokyo University Ethics Committee.

\section{Serum sample}

A total of 25 infertile women were recruited for the study. The mean age of subjects was 35.0 years (20-43 years). All of them had regular menstrual cycles of around 28 days duration. On day 3-5 of a spontaneous menstrual cycle, blood samples were obtained by venipuncture. The FSH concentration were measured using the immulite semiautomated assay system. Plasma for assay of AMH, BMP-2, 6, and 7 was separated immediately from blood and frozen in aliquots at $-80^{\circ} \mathrm{C}$ until thawed and assayed. A concentration of sensitivity, intra and inter-assay coefficients of variation respectively were as follow; BMP-2: $10 \mathrm{pg} / \mathrm{ml},<5 \%,<10 \%$, BMP-6: $80 \mathrm{pg} / \mathrm{ml},<10 \%$, $<12 \%$, BMP-7; $10 \mathrm{pg} / \mathrm{ml},<10 \%,<12 \%$, AMH: $70 \mathrm{pg} / \mathrm{ml},<13 \%,<15 \%$.

\section{Statistical analysis}

Data were analyzed by Pearson's correlation coefficient using Statview software (SAS Institute Inc., Cary, NC). A p-value of less than 0.05 was considered statistically significant.

Correspondence to: Osamu Yoshino and Yutaka Osuga, Department of Obstetrics and Gynecology, University of Tokyo, 7-3-1 Hongo Bunkyo-ku, Tokyo 113-8655, Japan, Tel: +81-3-3815-5411 (33407); Fax: +81-3-38162017; E-mail: oyoshino624@hotmail.co.jp, yutakaos-tky@umin.ac.jp

Key words: AMH, BMP cytokines, serum, infertility

Received: September 10, 2014; Accepted: September 21, 2014; Published: October 03, 2014 


\section{Result}

Knowing that BMPs significantly induced AMH mRNA in GC in vitro [4,5], we examined concentrations of BMP-2, -6, -7 and AMH in serum of infertile patients. Among 25 infertile patients, serum BMP-2, -6 , and -7 were detected only in $10,3,7$ patients respectively (Table 1 ), while $\mathrm{AMH}$ was detected in 24 out of 25 patients. Median serum levels of BMP-2, BMP-6, BMP-7, AMH and FSH were 0 (range $0-118$ ) pg/ml, 0 (range 0-673) pg/ml, 2.1 (range 0-37) pg/ml, $3.0(0-16.2) \mathrm{ng} / \mathrm{ml}$ and $9.2(1.0-38) \mathrm{mIU} / \mathrm{ml}$, respectively. The concentrations of serum BMP-2 and -7 were shown in Figure 1.

There was no correlation between the concentration of serum BMP-2, -6, -7 and concentration of AMH (data not shown). The concentration of serum FSH exhibited negative correlation with AMH concentration (Figure $2 \mathrm{r}=-0.41, \mathrm{p}=0.02$ ), but no correlation with BMP-2, -6 , or -7 (data not shown).

\section{Discussion}

Recently, AMH has been demonstrated to play an important role in ovarian function with its inhibitory effect on follicle recruitment, the process by which primordial follicles enter the growing pool of primary follicles [3]. Moreover, serum concentration of AMH is considered an excellent biomarker to estimate ovarian reserve of individuals in practical clinics [1,2]. In addition to AMH, BMP cytokines are known to be important intra-ovarian factors in the regulation of ovarian function [8]. We have reported that BMP-2, $-6,-7$ contribute to folliculogenesis by inducing $\mathrm{FSH}$ receptor and suppressing $\mathrm{LH}$ receptor expression in human GC $[4,10,14]$. Also, in the previous study, we have found that treatment with BMP-2, $-6,-7$ and $-15(100 \mathrm{ng} / \mathrm{ml})$ significantly increased AMH mRNA expression in human GC $[4,5]$.

In the present study, we investigated whether these BMPs, which have a potential to induce AMH expression, could be a marker

Table 1. The serum concentrations of bone morphogenetic protein (BMP)-2, -6, -7 and antimullerian hormone (AMH) of 25 infertility patients were measured. The cut off level and the patients' number of positive or negative for each cytokines were shown.

\begin{tabular}{|l|c|c|c|c|}
\hline \multicolumn{1}{|c|}{} & cut off & total & negative & positive \\
\hline BMP-2 & $10 \mathrm{pg} / \mathrm{ml}$ & 25 & 15 & 10 \\
\hline BMP-6 & $80 \mathrm{pg} / \mathrm{ml}$ & 25 & 22 & 3 \\
\hline BMP-7 & $10 \mathrm{pg} / \mathrm{ml}$ & 25 & 18 & 7 \\
\hline AMH & $70 \mathrm{pg} / \mathrm{ml}$ & 25 & 1 & 24 \\
\hline
\end{tabular}

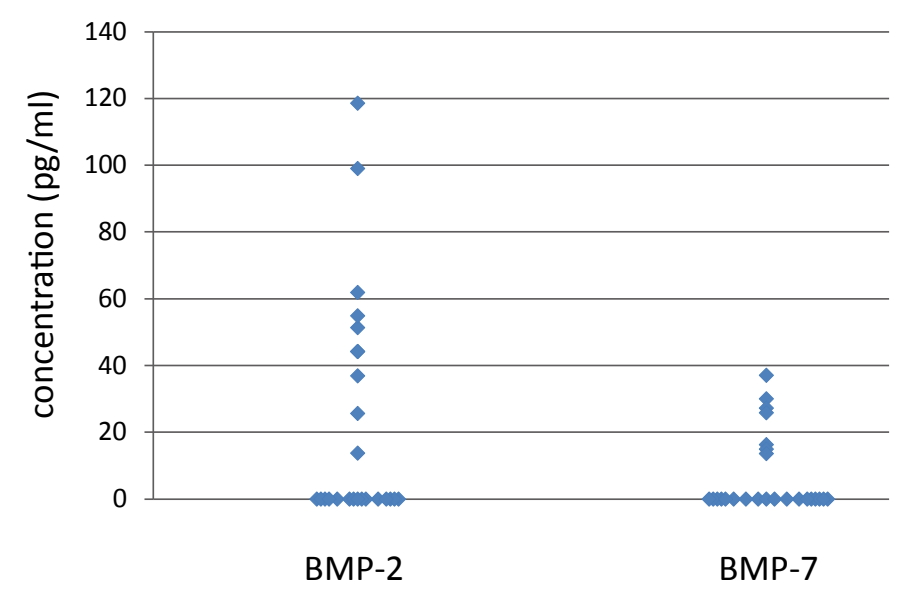

Figure 1. The serum concentrations of bone morphogenetic protein (BMP) -2 and -7 of 25 infertility patients were measured. The distribution of data was shown.

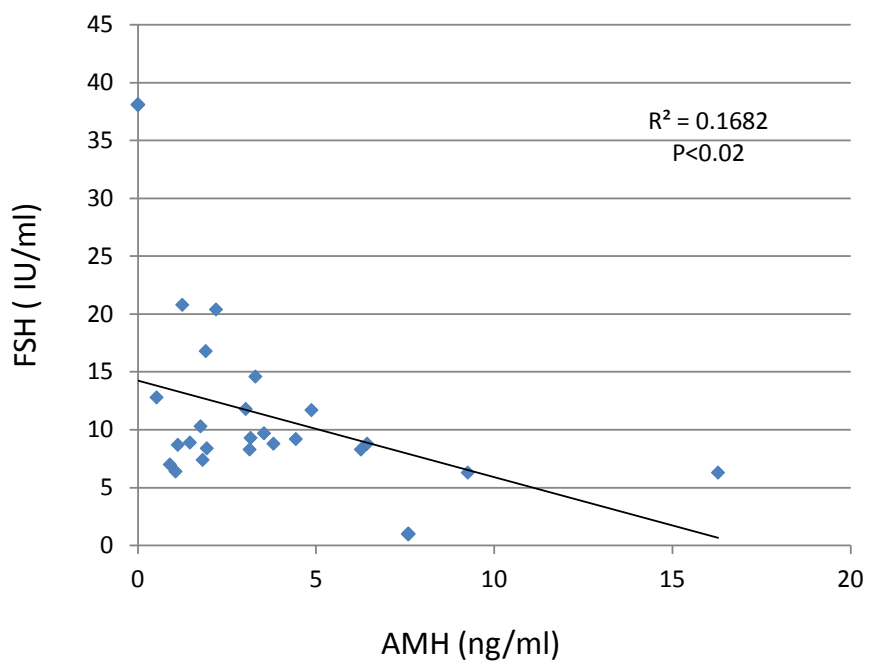

Figure 2. The serum concentrations of anti-mullerian hormone (AMH) and FSH of 25 infertility patients were shown. The concentration of serum FSH exhibited negative correlation with $\mathrm{AMH}$ concentration $(\mathrm{r}=-0.41, \mathrm{p}=0.02)$.

for ovarian reserve. Among BMPs, we evaluated BMP-2, 6, and -7 concentrations in the serum of infertile patients. Among 25 infertility patients, serum BMP-2, $-6,-7$ were detected in 10, 3, 7 patients respectively, while AMH was detected in 24 patients.

As $\mathrm{AMH}$ is known to be produced exclusively by GC, serum concentration of AMH might be a good marker [1,2]. We confirmed that the serum concentration of AMH showed negative correlation with that of FSH, which is consistent with previous studies $[1,2]$. Although in vitro study showed that AMH expression could be induced with BMP stimuli in GC $[4,5]$, the detection rate of BMP-2, -6 and -7 in serum was low, suggesting that comparing to AMH level, intra-ovarian BMP cytokines are not high enough to be reflected to serum level. Also, there was no relationship between serum BMP cytokines and $\mathrm{AMH}$ concentration. Since BMP-2, -6 and 7 are also produced in various organs including bone, adrenal gland, kidney, pituitary and pulmonary artery [14], the origin of these BMP cytokines in serum might not be specific to the ovary.

It is known that serum AMH is a good marker to predict a patient's ovarian reserve, but this has not been used successfully to predict the chance of achieving pregnancy $[15,16]$. Gode et al. reported that higher levels of mature growth differentiation factor (GDF)-9 protein, a member of BMP cytokine, in the follicular fluid were significantly correlated with oocyte nuclear maturation and embryo quality [17]. There is no study regarding the relevance between clinical outcome and levels of BMP-2, -6, and 7 in follicular fluid. Further study is needed to determine whether BMPs could be good markers to predict clinical outcome.

\section{Acknowledgments}

This work was supported in part by Health and Labor Sciences Research Grants from the Ministry of Health, Labor and Welfare of Japan, Grant-in-Aid for Scientific Research from the Ministry of Education, Culture, Sports, Science and Technology, Smoking Research Foundation (SRF) and The Grant of National Center for Child Health and Development (26-10). We thank Dr. Heather M. Martinez for her helpful discussion and critical reading of the manuscript. 


\section{References}

1. van Rooij IA, Broekmans FJ, te Velde ER, Fauser BC, Bancsi LF, et al. (2002) Serum anti-Müllerian hormone levels: a novel measure of ovarian reserve. Hum Reprod 17: 3065-3071. [Crossref]

2. Fanchin R, Taieb J, Lozano DH, Ducot B, Frydman R, et al. (2005) High reproducibility of serum anti-Mullerian hormone measurements suggests a multistaged follicular secretion and strengthens its role in the assessment of ovarian follicular status. Hum Reprod 20: 923-927. [Crossref]

3. Gruijters MJ, Visser JA, Durlinger AL, Themmen AP (2003) Anti-Müllerian hormone and its role in ovarian function. Mol Cell Endocrinol 211: 85-90. [Crossref]

4. Shi J, Yoshino O, Osuga Y, Koga K, Hirota Y, et al. (2009) Bone morphogenetic protein-6 stimulates gene expression of follicle-stimulating hormone receptor, inhibin/activin beta subunits, and anti-Mullerian hormone in human granulosa cells. Fertil Steril 92: 1794-1798. [Crossref]

5. Ogura-Nose S, Yoshino O, Osuga Y, Shi J, Hiroi H, et al. (2012) Anti-Mullerian hormone (AMH) is induced by bone morphogenetic protein (BMP) cytokines in human granulosa cells. Eur J Obstet Gynecol Reprod Biol 164: 44-47. [Crossref]

6. Lawson KA, Dunn NR, Roelen BA, Zeinstra LM, Davis AM, et al. (1999) Bmp4 is required for the generation of primordial germ cells in the mouse embryo. Genes Dev 13: 424-436. [Crossref]

7. Ross A, Munger S, Capel B (2007) Bmp7 regulates germ cell proliferation in mouse fetal gonads. Sex Dev 1: 127-137. [Crossref]

8. Shimasaki S, Moore RK, Otsuka F, Erickson GF (2004) The bone morphogenetic protein system in mammalian reproduction. Endocr Rev 25: 72-101. [Crossref]

9. Shi J, Yoshino O, Osuga Y, Koga K, Hirota Y, et al. (2011) Bone morphogenetic protein-2 (BMP-2) increases gene expression of FSH receptor and aromatase and decreases gene expression of LH receptor and StAR in human granulosa cells. $\mathrm{Am}$ J Reprod Immunol 65: 421-427. [Crossref]

10. Shi J, Yoshino O, Osuga Y, Nishii O, Yano T, et al. (2010) Bone morphogenetic protein 7 (BMP-7) increases the expression of follicle-stimulating hormone (FSH) receptor in human granulosa cells. Fertil Steril 93: 1273-1279. [Crossref]

11. Aaltonen J, Laitinen MP, Vuojolainen K, Jaatinen R, Horelli-Kuitunen N, Seppa L et al. (1999) Human growth differentiation factor 9 (GDF-9) and its novel homolog GDF-9B are expressed in oocytes during early folliculogenesis. $J$ Clin Endocrinol Metab 84:2744-2750. [Crossref]

12. Abir R, Ben-Haroush A, Melamed N, Felz C, Krissi H, et al. (2008) Expression of bone morphogenetic proteins 4 and 7 and their receptors IA, IB, and II in human ovaries from fetuses and adults. Fertil Steril 89: 1430-1440. [Crossref]

13. Yamoto M, Minami S, Nakano R, Kobayashi M (1992) Immunohistochemical localization of inhibin/activin subunits in human ovarian follicles during the menstrual cycle. J Clin Endocrinol Metab 74: 989-993. [Crossref]

14. Otsuka F (2010) Multiple endocrine regulation by bone morphogenetic protein system. Endocr J 57: 3-14. [Crossref]

15. Jayaprakasan K, Campbell B, Hopkisson J, Johnson I, Raine-Fenning N (2010) A prospective, comparative analysis of anti-Mullerian hormone, inhibin-B, and three-dimensional ultrasound determinants of ovarian reserve in the prediction of poor response to controlled ovarian stimulation. Fertil Steril 93: 855-864. [Crossref]

16. Broer SL, Mol BW, Hendriks D, Broekmans FJ (2009) The role of antimullerian hormone in prediction of outcome after IVF: comparison with the antral follicle count. Fertil Steril 91: 705-714. [Crossref]

17. Gode F, Gulekli B, Dogan E, Korhan P, Dogan S, et al. (2011) Influence of follicular fluid GDF9 and BMP15 on embryo quality. Fertil Steril 95: 2274-2278. [Crossref]

Copyright: (C2014 Ogura-Nose S. This is an open-access article distributed under the terms of the Creative Commons Attribution License, which permits unrestricted use, distribution, and reproduction in any medium, provided the original author and source are credited. 